\title{
Factors influencing the illegal harvest of wildlife by trapping and snaring among the Katu ethnic group in Vietnam
}

\author{
Douglas C. MacMillan and Quoc Anh Nguren
}

\begin{abstract}
The harvest of wildlife through hunting, trapping and snaring is illegal in Vietnam but remains widespread and is understood to be the major threat to many species. Clandestine activities such as trapping and snaring, which are deeply embedded in the culture and economy, are difficult to investigate and this study is the first to carry out in-depth research into the illegal capture and sale of wildlife by a major ethnic group in Vietnam. The research focused on two villages of the Katu, a forest-dwelling people living close to the boundary of the newly created Saola Nature Reserve, and involved collecting data from a focus group, 30 semi-structured interviews with trappers, and a number of informal, unstructured interviews with local forest rangers, forest officers and village headmen. We find that trapping is widespread and motivated by financial gain and non-pecuniary benefits such as social esteem and enjoyment, rather than by poverty per se. Trappers' awareness of wildlife protection law was low and animals were killed indiscriminately in traps and snares designed to catch a range of animal species. With demand for wildlife and wildlife products expected to increase we believe that new approaches will be required to protect threatened species in Vietnamese protected areas.
\end{abstract}

Keywords Illegal wildlife trade, Katu people, snaring, trapping, Vietnam

This paper contains supplementary material that can be found online at http://journals.cambridge.org

\section{Introduction}

$\mathrm{W}$ ildlife and other forest resources are considered economically important for c. 25 million people in Vietnam (World Bank, 2005). Although Vietnam is keen to promote the sustainable use and management of these resources (Government of Vietnam, 2006) there are, in reality, few strategies or funding opportunities in place to achieve this goal (Nguyen et al., 2007). Current policies are largely based on a legal framework that deems the taking of all wildlife illegal without a hunting certificate (Decision

Douglas C. MacMillan (Corresponding author) and Quoc ANH NgUYEN Durrell Institute of Conservation and Ecology, 14a Marlowe Building, University of Canterbury, Canterbury, CT2 7NR, UK. E-mail dcm@kent.ac.uk

Received 21 April 2012. Revision requested 2 July 2012.

Accepted 19 October 2012. First published online 16 October 2013.
186/2006/QD-TTg and Decree 32/2006/ND-CP). No such certificates have been issued, hence all trapping is effectively perceived as being illegal even outside protected areas (Long, 2005; Roberton, 2007).

Although efforts have been made by agencies at different levels to reduce the illegal wildlife harvest, for example by confiscating guns, these have been largely unsuccessful. Trapping and snaring are widespread throughout the country and Vietnam is a key player in the illegal wildlife trade network, as both a source of meat and other wildlife products, and as a significant consumer of wildlife (Compton \& Le Hai Quang, 1998; Bell et al. 2004; Lin, 2005). Furthermore, it is believed that many threatened species in Vietnam, such as the saola Pseudoryx nghetinhensis, Annamite muntjac Muntiacus truongsonensis, and redshanked douc langur Pygathrix nemaeus are threatened with extinction as a result of trapping and snaring (Baltzer et al., 2001; Long et al., 2005; Timmins et al., 2008a,b,c).

Legal measures to control resource use often fail for a variety of reasons connected to funding, malfunctioning administration, and corruption but as Nguyen et al. (2007) point out in the context of Vietnam, a major problem is that the legal framework does not accommodate the livelihood needs of local people or what they perceive to be their traditional rights to take wildlife. To develop a more effective conservation policy it is therefore imperative that we understand better the motivation for wildlife utilization from the perspective of the local communities in and around protected areas in Vietnam.

Here we build on earlier research by Long (2005) to inform future policies on wildlife utilization in Vietnam, by developing an in-depth understanding of the lives and aspirations of a small targeted sample of individual trappers in the buffer zone of a protected area in Quangnam Province. Our specific aims are to identify and explore the motivation and decision-making related to wildlife capture and/or killing (e.g. decisions about what, where, when, how and how much to hunt), to quantify the relative importance of trapping in terms of household income, and to explore how important wildlife is perceived as an economic resource for the future. Hereafter we use the terms trapping, and trapper, as this is the main way that wildlife is killed in Vietnam.

\section{Study area}

The villages of Arec and Bhohoong were chosen for the study because they are in the buffer zone of Saola Nature 


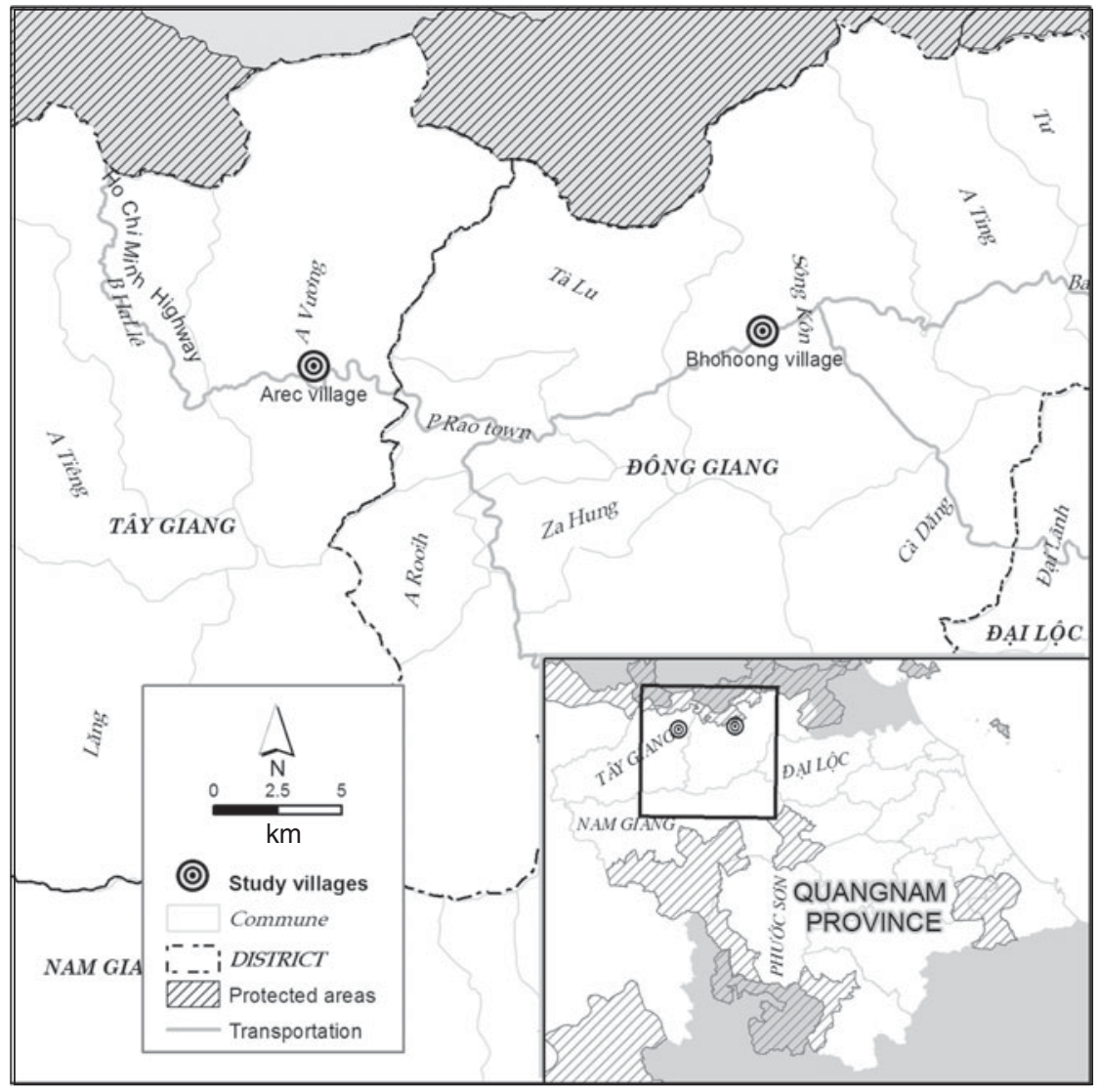

FIG. 1 The location of the two study villages of Arec and Bhohoong in the buffer zone of Saola Nature Reserve in Quangnam Province. The inset indicates the location of the main map in Vietnam.
Reserve in Quangnam Province (Fig. 1) and because the Katu people that live there have traditionally relied on wildlife utilization for their livelihood. The Katu ethnic group is one of Vietnam's 53 officially recognized minorities. Numbering c. 50,000, the Katu live in the mountainous regions of Quangnam and Thuathien-Hue Provinces along the border with Lao PDR (Arhem, 2009). Saola Nature Reserve was established in February 2011 but had been designated as a Special Use Protected Forest from 2007.

Arec village belongs to the A Vuong commune, Tay Giang district, and is c. $2 \mathrm{~km}$ from the Ho Chi Minh Highway (built in 2006) and $6 \mathrm{~km}$ from the boundary of the Saola Nature Reserve. The road condition from the Ho Chi Minh Highway to the village is poor, being unsuitable for most vehicles, although communications have improved recently as a result of the mobile phone network. All 79 households present in Arec at the time of the study were Katu and 71 of these are classed as 'poor', equivalent to a total income of $<$ VND 400,000 (USD 20) per person per month, and the remainder as 'near poor', equivalent to VND 401,000-520,000 (USD 21-27) per person per month (Government of Vietnam, 2010)

Bhohoong village belongs to the Song Kon commune in Dong Giang district. It lies c. $6 \mathrm{~km}$ from the boundary of the Saola Nature Reserve and was established in 1975 when the community was moved from Taygiang district on government orders. This village is located nearer to National Road 1 and Danang City than is Arec, and many people live in close proximity to this road. Bhohoong is predominately composed of Katu people ( 65 of 69 households), with 3 Kinh (the main ethnic group of Vietnam) and 1 Thai household (s). The Bhohoong community is not as poor as that in Arec, with 42 of the households classified as 'poor' and the remainder as 'near poor'.

\section{Methods}

Although it was known that there were many trappers in both Arec and Bhohoong, our research approach had to reflect the potentially sensitive nature of the data to be collected as trapping is officially an illegal activity. Different approaches have been developed to gain information about illegal behaviour, such as the non-randomized response technique (Solomon et al., 2007; St-John et al., 2010) that can be deployed when the open acknowledgement of illegal activity is unlikely given the severity of the penalties and the chances of prosecution. But in our situation, where illegal killing of wildlife is pervasive and the law is not enforced, we chose a more direct approach involving confidential and informal semi-structured interviews. This approach has proved fruitful where clandestine activities can be discretely discussed within the community with 
a trusted researcher (Pratt et al., 2004; MacMillan \& Han, 2011).

Before interviewing began the researcher spent time in the village participating in and observing daily social events and activities, including going to the forest with trappers. This provided an opportunity to understand the trappers' daily lives and to build trust with the local community (MacMillan \& Phillip, 2010). In keeping with local custom, interviewees were also given small gifts.

The research focused on gaining knowledge about the nature of trapping (how, what, where, when and how much), motivations for trapping, past and future trends in trapping activity, and the views of trappers about the current legal and policy framework governing trapping of wildlife. The research was carried out from 7 May to 4 July 2011 and consisted of four main activities: (1) Key informant interviews: informal and unstructured interviews with, for example, local rangers, forest officers and headmen of villages, to obtain general information about trapping, economic conditions and the culture and customs of people in the villages prior to interviews with trappers. (2) Focus group: a small group of trappers were brought together to explore general issues about trapping and to help develop the semi-structured questionnaire. (3) Interviews with trappers: from information supplied by key informants it was believed that every household in both villages, with one exception, was or had been involved in trapping but that some $(<10 \%)$ were not currently active for health or reasons of age or, in the case of one Bhohoong villager, because he had a well-paid position in district government and had no time to hunt. Because of time limitations it was only possible to carry out semi-structured interviews with a sample of trappers, comprising 13 active trappers and two former trappers in Arec village and 13 active trappers, one former trapper, and one non-trapper in Bhohoong village. Because we were primarily interested in the conservation of threatened species such as the saola, trappers who made trips deep into the forest interior $\left(>_{2} \mathrm{~km}\right.$ or $>2$ hours' journey from the village) were sought out as they were most likely to encounter and have the opportunity to kill threatened species. Interviewees were identified through snowball sampling (Newing et al., 2011), with an initial introduction by the headman of the village. The questions used in the semi-structured interviews are provided in the Supplementary Material. When there was > one trapper per household only the main trapper was interviewed. (4) Triangulation interviews: to ensure accuracy the data were triangulated by checking information with local forest rangers, the interviewees' family and with outsiders who were working in the study villages (Baxter \& Eyles, 1997).

All interviews were conducted in Vietnamese and were recorded if the interviewees agreed, otherwise notes were taken. Vietnamese Dong (VND) was used as the unit of currency and all conversions to USD used the rate of exchange prevailing on 2 June 2011 (USD $1=$ VND 20,520). Interview data was coded using broad codes defined in advance, in line with our research objectives, with detailed codes and sub-codes developed later on, according to what emerged from the data. Notes from informal/unstructured interviews with targeted people were cross-referenced when specific information was mentioned during the semi-structured interviews with trappers. Quantitative data were analysed using SPSS v. 16.0 (SPSS, Chicago, USA). Independent 2-tailed $t$ tests were used to test for significant differences in trap number, trapping result and trapping income per trapper between the villages. One-way ANOVA was used to test for significant differences in the price per $\mathrm{kg}$ between species, using a logarithmic transformation because the data were not normally distributed. Regression analysis was used to determine whether the value of a species was associated with the number of individuals of each species hunted.

\section{Results}

\section{Organization, methods and effort}

A total of 16 of 26 currently active trappers (8/13 in Arec; 8/13 in Bhohoong) visited the forest interior to set traps and snares, whereas the remainder were active only around their farmland. Many of those who trapped only around farmland had previously gone on trapping trips to the forest interior but had stopped doing so because of their age, or the increasing scarcity of wildlife.

All 26 trappers confirmed they used only home-made traps. Older forms of trapping such as bow and arrow were no longer used because traditional skills and knowledge of such techniques (such as how to find and extract the poison applied to the arrowhead) had been lost, or they were not as cost-effective as trapping and snaring. Both of these methods are cheap and easy to deploy, typically bicycle or motorbike brake wire being the only material not available on-site. Log-fall traps were used by 23 of the trappers, and snap traps for rodents were used by 13 of the trappers. Respondents would always carry a spear, which could be used to finish off large animals caught in their traps. Unlike in other areas of Vietnam, dogs are not used because they could be killed or injured by the snares and traps. There were rumours that some trappers kept guns hidden in the forest interior but this was not mentioned by any of the trappers interviewed and could not be confirmed.

Trapping in the forest interior was usually undertaken solo, or in small groups of 3-8 people, typically comprising relatives and/or friends, especially when large animals were being targeted. Occasionally much larger groups would set off for the forest interior to mark a special event such as a wedding. These social hunts would last $4-7$ days and would be led by the village headman, and could involve driving 
TABLE 1 Number and type of animals caught around the villages of Arec and Bhohoong (Fig. 1) between April 2010 and March 2011.

\begin{tabular}{|c|c|c|c|}
\hline \multirow[b]{2}{*}{ Village } & \multirow[b]{2}{*}{ Respondent category } & \multicolumn{2}{|c|}{$\begin{array}{l}\text { Mean no. of animals } \\
\text { per trapper per year }\end{array}$} \\
\hline & & $\begin{array}{l}\text { Small \& medium } \\
\text { species }\end{array}$ & $\begin{array}{l}\text { Large } \\
\text { species }\end{array}$ \\
\hline \multirow[t]{2}{*}{ Arec } & $\begin{array}{l}\text { Forest interior } \\
\& \text { farmland }\end{array}$ & 143.5 & 4.1 \\
\hline & Farmland only & 27.4 & 1.0 \\
\hline \multirow[t]{2}{*}{ Bhohoong } & $\begin{array}{l}\text { Forest interior } \\
\text { \& farmland }\end{array}$ & 163.6 & 4.6 \\
\hline & Farmland only & 36.9 & 1.1 \\
\hline
\end{tabular}

large game towards men waiting with spears. The bride and groom's family would pay for the food consumed during the trapping and fishing trips. Closer to the village and around cultivated land, trapping and snaring were carried out alone.

On average trappers who went into the forest interior set c. 150 traps per year, $>70 \%$ of which were laid deep in the forest. Trappers who only hunted around cultivated land set fewer traps/snares on average (c. 40 per year). There was no significant difference between the two villages in the number of traps set in the forest interior $(t=-1.660$, $\mathrm{df}=14, \mathrm{P}=0.119, \mathrm{n}=8$ ) or in the number of traps set around the farms $(t=-1.118, \mathrm{df}=24, \mathrm{P}=0.275, \mathrm{n}=13)$. The most active season for trapping is from August to January. Traps and snares close to the village are usually checked on a daily basis but this could vary depending on the season and location. For traps in the forest interior members of the village/group took turns to check the traps because of the amount of time involved. All 26 trappers currently active said they normally took a day to check traps, including traps in the deep forest, and could set 15-20 new traps per day on average. Trappers went to the forest interior for longer (c. 4-10 days) when they were setting up new traps or renewing traps before the trapping season, or when they were participating in social events. The amount of time spent snaring and trapping in any given year was mainly determined by time constraints because of other activities (e.g. farming crops, planting rubber trees, harvesting non-timber forest products) and by the weather. Around farmed land it was customary only to set traps and snares around areas that the trapper farmed. There was no overall control or regulation of trapping in terms of location or number of traps set in the forest interior.

\section{Species caught}

Snares and traps are to some extent indiscriminate in terms of the species caught although trappers can use their skills and knowledge of animal movement to target species

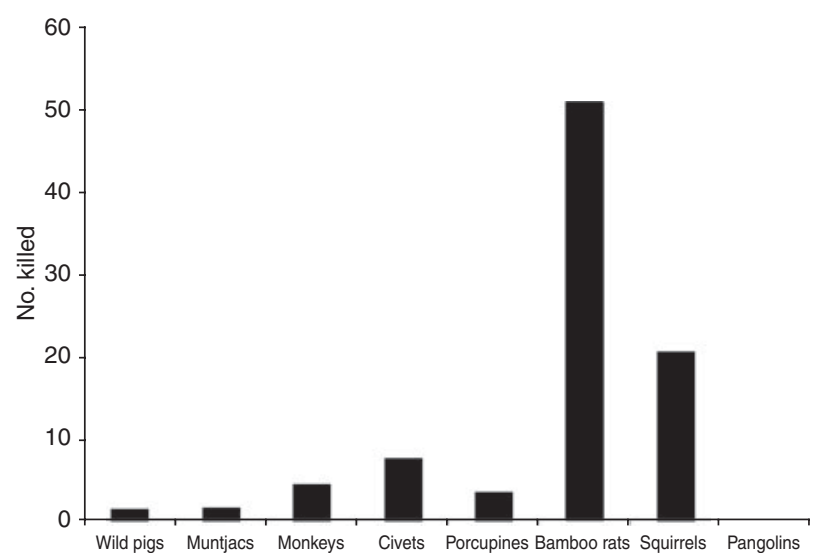

FIG. 2 Mean number of animals killed between April 2010 and March 2011 per trapper (averaged across both villages).

to a limited extent. Table 1 summarises the annual harvest of animals for the 26 hunters interviewed. Small- and mediumsized species such as the Asian brush-tailed porcupine Atherurus macrourus and bamboo rat Rhizomys sinensis ( $\mathrm{Cu} \mathrm{Lui} \mathrm{in} \mathrm{Katu),} \mathrm{were} \mathrm{caught} \mathrm{more} \mathrm{frequently} \mathrm{than} \mathrm{larger}$ mammals such as the wild pig Sus scrofa and muntjac Muntiacus muntjak, because larger animals are now rare, especially around farmland.

Trappers reported considerable variation in harvest between forays and sometimes no animal would be trapped for up to a month. This variation was believed to be because of the animals' characteristics, trapper skill (quality of and location of snares) and luck. Most animals were caught in the forest interior because of the higher number of traps laid and the density of wildlife there. There was no significant difference between the villages in the number of animals caught in the deep forest $(t=-1.491, \mathrm{df}=14, \mathrm{P}=0.158)$ but the number of animals taken around farmland was significantly higher in Bhohoong $(t=-3.356, \mathrm{df}=24$, $\mathrm{P}=0.003$ ), probably because it is closer to the forest.

Fig. 2 shows the number of animals killed per trapper in the 2010 season, averaged across trappers from the two villages. The species most frequently caught were squirrels (Ratufa spp,) and bamboo rats, with a mean of 50 and 20 respectively (although some trappers reported catching up to 200 rats). The most commonly taken large mammals were macaques (Macaca spp.), wild pigs and muntjacs, with c. 2 or 3 individuals taken per trapper per year. Macaques such as the bear macaque Macaca arctoides, northern pigtailed macaque Macaca leonina and long-tailed macaque Macaca fascicularis could be trapped when they descend from trees to search for food and water on the ground (although if the rumours about guns hidden in the forest are true then they could also be shot when in the trees). Pangolins Manis javanica were rarely caught (only seven were caught in 2010) but were highly sought after because of the high price they could fetch (VND 10,000,000, USD 500). 


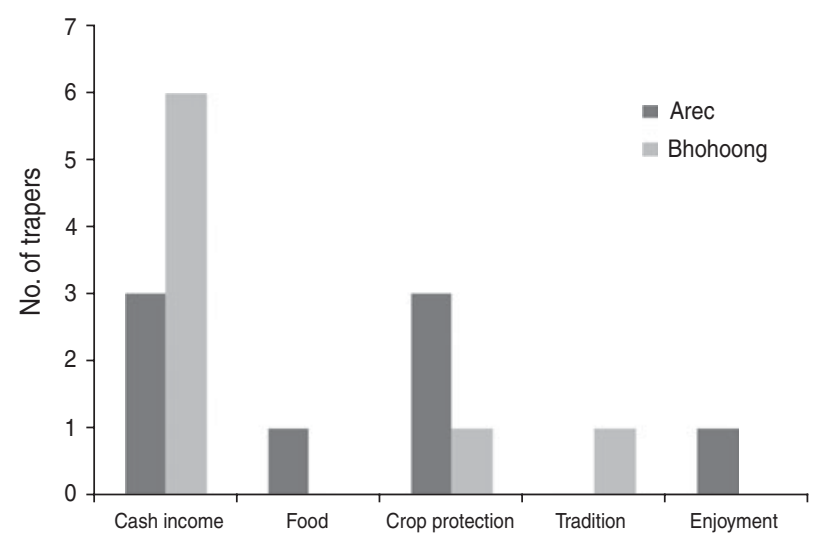

Fig. 3 Primary motivation for trapping (number of trappers who went to forest interior only).

Although there are significant differences between species in price per $\mathrm{kg}\left(F_{7,135}=832.113, \mathrm{P}<0.001\right)$ and there was a recognition that trappers should always try to catch the higher value species, there was no linear relationship between the price of the species and number of individuals of a species caught $\left(F_{1,6}=0.428, \mathrm{P}=0.537\right)$. This is largely because of the indiscriminate nature of snaring and the lack of opportunity to target high value species because there are no specialized methods for catching them.

\section{Motivation}

Among all trappers who trapped only around their farmland (10/10), crop protection was the main motivation for trapping. The opportunity of earning additional cash income was the most commonly cited motivation of trappers who visited the forest interior, especially in Bhohoong (Fig. 3), because there was a chance of catching more valuable species that could be sold in the market, such as pangolins, pigs and monkeys ( $9 / 16$ trappers). Other main motivations were crop protection $(4 / 16)$, food $(1 / 6)$, enjoyment $(1 / 16)$ and tradition $(1 / 16)$.

Animal parts and products were used within the family, shared in feasts for all the households in the village or were sold to wildlife traders or restaurants in the nearby towns. Small-sized mammals, such as squirrels, rats and civets (Paradoxurus spp.) were normally consumed by the family, whereas bamboo rats and porcupines, with higher market value, were sold (Table 2). Larger mammals such as wild pigs or muntjacs were used for communal feasts and other eating events, or sold to market traders. Species hunted primarily for the market such as pangolins and wild pigs had high value as meat, pets or for medicine.

Trappers in Bhohoong village were more commercially oriented and tried as much as possible to sell animals to traders, only eating those animals that could not be sold. Evidence of a more commercial approach was the expectation that village feasts would only occur if an animal could not be sold. In Arec trapping retains a more traditional role, with customs such as drumming and playing gongs to inform villagers when a big animal is caught. Also, Arec trappers tend to sell only animals that have high value (e.g. pangolins) and on average sold only c. $7 \%$ of small- and medium-sized animals and $20 \%$ of larger mammals hunted, whereas Bhohoong trappers sold c. 40 and $60 \%$, respectively. According to custom in both villages all trappers believed that they should retain the head, tail, legs, heart, liver and intestines of the wild animal when it is sold to traders, to ensure good luck in future trapping forays.

Although only two of 26 active trappers stated that enjoyment or tradition was their primary motivation, all trappers appeared to value their traditional role, took pride in their prowess, and enjoyed their status by frequently hosting feasts for their friends and relatives. According to one older trapper:

Even if I can get enough food for living from other livelihoods I still like to go to the forest to hunt until my health would not be strong enough for trapping, because I want to make more money for my family and of course I like trapping.

\section{Economic significance}

In 2010 the cash income gained from trapping was four times higher in Bhohoong than in Arec (Table 3). This difference was largely because of the remoteness of Arec and its consequent lack of accessibility to wildlife dealers. In Arec trappers who want to sell meat have to carry it to the nearest road $15 \mathrm{~km}$ away, whereas Bhohoong is situated close to a main road where there are more wildlife dealers and more opportunity to obtain a good price. Occasionally, dealers would come to Arec but only if they had been informed that big animals (e.g. wild pig) or valuable species (e.g. pangolin) had been caught. There is no evidence from our interviews that poorer households kill more wildlife, and there were no difference in the number of traps set by Bhohoong and Arec interviewees in the forest interior.

Trappers who hunted in the deep forest earned c. $15-20 \%$ of total household income from wildlife. For those active only around cultivated land, income from trapping was only c. $5 \%$ of total household income. Across all categories of economic activity wildlife trapping was only the fourth highest source of household income. The main source was cultivation of crops such as cassava, rice and maize, which accounted for c. $35-45 \%$ of total household income, followed by pensions and other jobs, and non-timber forest products (Table 3). The additional income from wildlife was useful for buying extras (e.g. goods from the town) and helped contribute to larger capital investments (motorbikes) 
TABLE 2 The uses and sale price of harvested animals, by species

\begin{tabular}{lllllr}
\hline & \multicolumn{2}{l}{ Trade } & & & \\
\cline { 2 - 5 } Species & Medicine & Meat & Pet & Subsistence & Price per kg (USD) \\
\hline Wild pig Sus scrofa & & $\mathrm{X}$ & & $\mathrm{X}$ & 7.75 \\
Muntjac Muntiacus muntjak & $\mathrm{X}$ & $\mathrm{X}$ & & $\mathrm{X}$ & 4.19 \\
Macaques (Macaca spp.) & & $\mathrm{X}$ & & 3.95 \\
Civets (Paradoxurus spp.) & & $\mathrm{X}$ & $\mathrm{X}$ & 5.94 \\
Asian brush-tailed porcupine Atherurus & & $\mathrm{X}$ & $\mathrm{X}$ & 5.75 \\
$\quad$ macrourus & & $\mathrm{X}$ & $\mathrm{X}$ & $\mathrm{X}$ \\
Bamboo rat Rhizomys sinensis & & $\mathrm{X}$ & $\mathrm{X}$ & 5.80 \\
Squirrels (Ratufa spp.) & $\mathrm{X}$ & $\mathrm{X}$ & \\
Pangolin Manis javanica & & & 5.65 \\
\hline
\end{tabular}

TABLE 3 Cash income from wildlife capture and percentage annual household income from different sources in Arec and Bhohoong villages (Fig. 1) in 2010.

\begin{tabular}{|c|c|c|c|c|c|c|c|}
\hline \multirow[b]{2}{*}{ Village } & \multirow[b]{2}{*}{ Respondent category } & \multirow[b]{2}{*}{$\begin{array}{l}\text { Income per } \\
\text { trapper (USD) }\end{array}$} & \multicolumn{5}{|c|}{$\%$ income source } \\
\hline & & & Trapping & Livestock & NTFPs* & Crops & $\begin{array}{l}\text { Other (pension, } \\
\text { other jobs) }\end{array}$ \\
\hline \multirow[t]{2}{*}{ Arec } & Forest interior \& farmland & 79.92 & 15 & 2 & 25 & 40 & 18 \\
\hline & Farmland only & 15.65 & 5 & 2 & 25 & 45 & 22 \\
\hline \multirow[t]{2}{*}{ Bhohoong } & Forest interior \& farmland & 352.53 & 20 & 2 & 21 & 35 & 22 \\
\hline & Farmland only & 79.80 & 5 & 2 & 20 & 45 & 28 \\
\hline
\end{tabular}

${ }^{\star}$ Non-timber forest products

and educational and health services. According to one Bhohoong trapper:

My expectation when going to the forest to hunt is that I could catch as many animals as possible in order to sell and gain high cash income for buying things for family, especially for my children learning in the school.

Although trapping was of only modest significance as a source of income, most trappers and former trappers believed that they led a better life than non-trappers. Also, all respondents declared that successful trappers enjoyed respect for their intelligence, skills and hard work. It was also clear that trappers could gain other economic benefits from their activities; e.g. wildlife dealers (usually Kinh people from nearby settlements) would lend money or sell goods on credit to trappers in the expectation that they would have priority when animals become available for sale.

The costs of trapping were low, with materials used for making traps easy to source and buy. Bicycle brake wires are used to make most snares, with a cost of $c$. VND 4,000-5,000 (USD 0.20-0.24) per snare. Other materials (e.g. for log-fall traps), were typically collected in the forest. In terms of other costs, food costs on forays were minimal, as trappers typically took only rice with them, supplementing their rations on longer trips with fish or small animals such as frogs and squirrels that they caught in the forest.

\section{Trends}

Prices have increased in recent times because of demand for meat by restaurants and dealers, especially for high value species such as pangolin and wild pig. Despite the higher prices on offer, the number of villagers trapping in the forest interior, the number of traps per trapper and the mean time spent trapping had all decreased in the previous 5-10 years, according to all trappers currently active (Fig. 4). The reasons given were that all wildlife species, especially higher value animals, are becoming increasingly rare and more difficult to kill without guns.

Most trappers believed wildlife was becoming scarcer because of the decline in the area and quality of forest as a result of illegal logging (11/13 respondents in Bhohoong and 6/13 respondents in Arec) or excessive trapping pressure (4/13 respondents in Arec). Other respondents had no opinions about this issue. Respondents in Bhohoong reported that illegal logging and poaching was largely by outsiders (mainly Kinh people) who had come from Thuathien Hue (a neighbouring province) or from the lowlands of QuangNam. Many believed that illegal loggers would also trap intensively during the time they were in the forest, to make money and to eat. In Arec, trappers said there were few cases of outsiders coming to hunt in their areas because traditional trapping areas exist for each village and outsiders cannot easily gain access because of the more remote location of the village. 


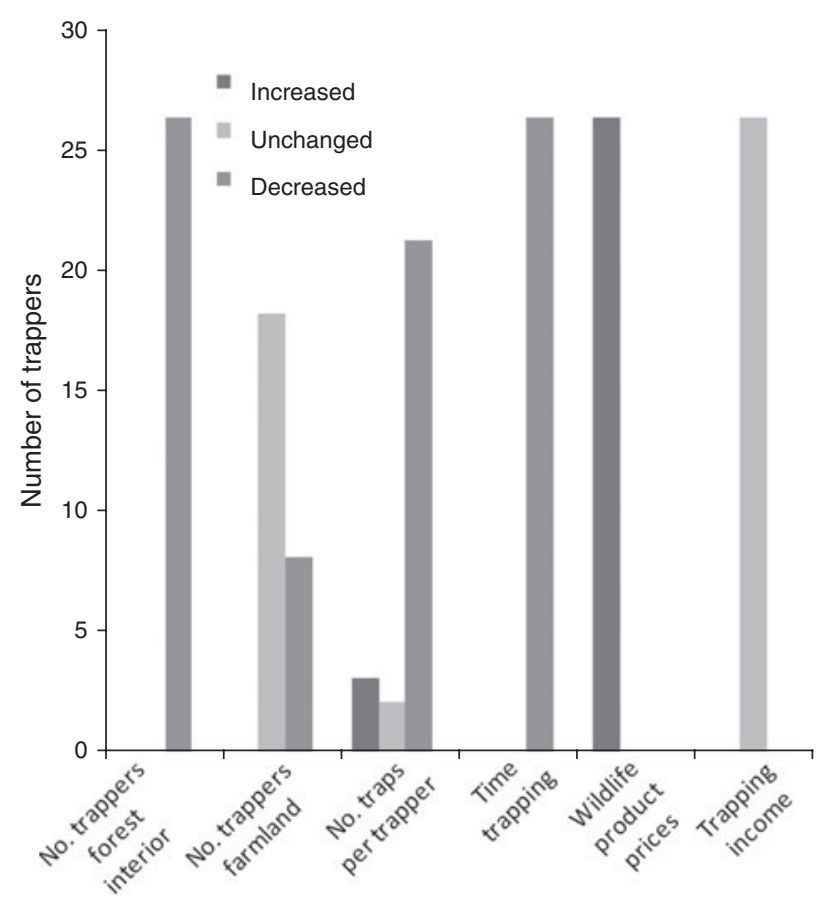

FIG. 4 Trends in trapping compared to 5-10 years ago, according to all trappers currently active (number of trappers).

Although all respondents had taught, or were willing to teach their sons trapping skills, only $8 / 20$ stated they wanted their sons to continue trapping as an occupation, with most (12/20) wanting their children to have better jobs in 'the town'. This is a similar finding to other studies that have found little enthusiasm among hunters for their children to become reliant on traditional livelihoods such as wildlife capture (Gubbi \& MacMillan, 2008). However, a trapping education was seen as a form of insurance policy, providing backup in case other things did not work out. According to one trapper:

I would like to support my sons to study at school and wish they could get the good jobs at the town or city, but if they give up (studying) they should continue my job and go to the forest to hunt... of course, I have taught them how to hunt from when they were sixteen year old.

Trappers' perceptions of legislation and sustainable trapping

All respondents (26/26) were aware that trapping was strictly prohibited in Saola Nature Reserve but felt that the boundary of the new protected area was not clearly identified by the local authorities. Most trappers (24/26) knew they were not permitted to hunt some of the threatened species (e.g. saola, black bear Ursus thibetanus and pangolin) but nobody knew what the punishment was. Furthermore, no one had ever been punished by local authorities for trapping or trading.
Most trappers (20/26) were aware of a decline in wildlife, some of which (e.g. saola and the tiger Panthera tigris) have almost certainly disappeared from the local forest or have become rare (e.g. bears, box turtle Cuora galbinifrons, various snake and deer species). Many (18/26) believed that several species had totally disappeared. However, when asked about the reasons for the declines only 4/13 interviewees in Arec and 1/13 interviewee in Bhohoong stated that trapping was the major reason. However, most trappers were open to the idea of reducing trapping in protected areas provided they could continue to trap around their fields to protect their crops, and to catch species, such as wild pigs, which are still abundant.

\section{Discussion}

Although key indicators such as number of trappers, number of traps being set, and income from wildlife were all reported to be in slow decline, strong purposeful intervention will be required in the short term to avoid further losses of biodiversity and possible extinctions. Gaining the support and trust of the local community is critical to the conservation effort and here we discuss some potential actions that could be taken based on our understanding of current practices, the existing policy framework, and the social, economic and cultural role of wildlife harvesting in Quangnam Province.

Conservation authorities should consider relaxing the complete ban on harvesting wildlife. Local trappers appear to be reconciled to the idea of ending illegal trapping of threatened species within the protected area if they are allowed to trap wildlife around their farmland, especially large species, such as the wild pig, which damage their crops. Such an agreement is currently being piloted in Bachma and Xuanthuy National Parks, where non-threatened species can be taken inside the protected area under the national hunting certificate scheme (Decision 126 of Government of Vietnam (2012) and, based on what we learned from local trappers, such an approach could work villages of Arec and Bhohoong.

Although this approach may be problematic, according to several of the government rangers we interviewed, because it could be perceived as official support for the commercial trade in wild animals, we believe this risk could be countered if the ban on the sale of wild meat for commercial gain is more strongly enforced. Allowing animals to be killed, but not sold for commercial gain, has been used effectively in other situations, for example to conserve wildlife such as the barnacle goose Branta leucopsis in Scotland (MacMillan et al., 2004) and wild deer Odocoileus virginianus in the United States (Messmer et al., 1997), but it would require more resourcing, including enforcement effort, than is currently in place. At the same time the government needs to crack down on illegal 
harvesting of timber as the villagers perceive this to be a big threat to wildlife and they are unlikely to restrict their activities if outsiders are taking valuable species from within the protected area.

Given that legal measures to protect wildlife are largely ignored because of low enforcement effort and the considerable economic and cultural importance of wildlife, there is a possibility that the legal approach on its own would not be fully effective and the government could find itself investing significantly in law enforcement with little return. Hence a supplementary approach involving, for example, community payments, enhanced pension payments or the free provision of health and education services should also be considered. Such payments could be made strictly conditional on there being no further trapping in the protected area and could include paying trappers to provide a community ranger service to deter poaching wildlife and illegal tree felling by outsiders. Similar payment schemes are already being piloted in sensitive water catchments used for hydroelectric power in Vietnam, including Quangnam (Nguyen, 2011). Although MacMillan \& Leader-Williams (2008) highlighted some of the drawbacks to incentive payment systems for wildlife management, they could be an appropriate short-term measure at a time when wildlife values are increasing and populations are decreasing rapidly.

Although local people have much of the necessary knowledge (Newton et al., 2008) to manage the forest resources sustainably, some investment will be required to build capacity and influence wildlife utilization in favour of conservation objectives. For example, a social marketing programme to raise trappers' awareness of threatened species and respect for wildlife protection law would be necessary as many respondents were unaware of the boundaries of Saola Nature Reserve and of which species are considered threatened and therefore most in need of protection. Furthermore, as trapping is a non-selective form of wildlife capture, innovative programmes that build on local tradition and culture could be introduced to target species more effectively. For example, support and encouragement to organize traditional hunts of wild pig using spears, or a village feast programme, sponsored by an NGO or tourism enterprise, to celebrate the rescue and release of a threatened species from a trap. Although, there are significant challenges inherent to such an approach, especially in the tropics (Bodmer \& Lozano, 2001) it is, in our view, necessary for a more equitable and sustainable policy for wildlife capture and utilization in Vietnam. Further in-depth research with the communities, relevant NGOs and government agencies to explore any such measures would, however, be required.

Our research and recommendations touch on sensitive and difficult issues for villagers and government alike. The insights we gained into illegal trapping was largely a result of the nature of our research methodology, which combined qualitative and quantitative data developed from a mixture of participant observation and in-depth interviewing. However, the data presented are only an accurate reflection of the situation in two villages at one point in time and our conclusions and recommendations must be considered in this light. Further studies in other communities and over longer time-frames are desirable, as they would allow a clearer national picture to emerge.

\section{Acknowledgements}

This project was funded by the Durrell Institute of Conservation and Ecology, University of Kent, UK, and a Darwin Initiative project jointly managed by the University of Cambridge and WWF-Vietnam entitled 'Can trapping and conservation of endemic Annamite ungulates be reconciled?' We greatly appreciate the support of WWFVietnam, in particular Dr Van Ngoc Thinh, Country Director. The project would not have been possible without the support and cooperation of the Forest Protection Department of Quangnam Province and the Management Board of Quangnam Saola Protected Areas. We thank N. Wilkinson, Project Officer of the Darwin project in Vietnam, for his advice regarding working with communities, Dan Challender for valuable comments on the text, and two anonymous referees for their helpful comments.

\section{References}

Arhem, N. (2009) In The Sacred Forest Landscape, Livelihood and Spirit Beliefs among the Katu of Vietnam. SANS Papers in Social Anthropology 10, University of Gothenburg. Gothenburg, Germany.

Baltzer, M.C., NguYen, Thi DAo \& Shore, R. (eds) (2001) Towards a Vision for Biodiversity Conservation in the Forests of the Lower Mekong Ecoregion Complex-Technical Annex. WWF-Indochina Hanoi, Vietnam, and WWF-US, Washington, DC, USA.

BAXter, J. \& Eyles, J. (1997) Evaluating qualitative research in social geography: establishing 'rigour' in interview analysis. Transactions of the Institute of British Geographers, 22, 505-525.

Bell, D.J., Roberton, S.I. \& Trapper, P.R. (2004) Animal origins of SARS coronavirus: possible links with the international trade in small carnivores. Philosophical Transactions of the Royal Society B, 359, 1107-1114.

Bodmer, R.E. \& Lozano, E.P. (2001) Rural development and sustainable wildlife use in Peru. Conservation Biology, 14, 1163-1170.

Compton, J. \& Le HaI, Quang (1998) Borderline: An Assessment of Wildlife Trade in Viet Nam. WWF-Indochina Programme, Hanoi, Vietnam.

Government of Vietnam (2006) Decree No. 32/2006/NĐ- CP by The Prime Minister dated 30/3/2006 on rare, endangered wild animals and plants management.

Government of Vietnam (2010) Instruction No. 1752/CT-TTg by The Prime Minister dated 21/9/2010 on surveying poor households for social strategy 2011-2015. 
Government of Vietnam (2012) Prime Minister Decision No. 126. Pilot policy on benefit sharing mechanism (BSM) in management, protection and development of special-use forests (SUFs).

Gubbi, S. \& MacMillan, D.C. (2008) Can non-timber forest products solve livelihood problems? A case study from Periyar Tiger Reserve, India. Oryx, 42, 222-228.

Lin, J. (2005) Tackling Southeast Asia's illegal wildlife trade. Singapore Year Book of International Law (SYBIL), 9, 191-208.

LoNG, B. (2005) Identification of priority areas for integrated conservation management in Quang Nam province. $\mathrm{PhD}$ thesis. University of Kent, Canterbury, UK.

Long, B., Van Thuong,, H. \& Truyen, T. (2005) Developing Strengthened Biodiversity and Natural Resource Law Enforcement in Quang Nam Province. WWF-Vietnam, Tam Ky, Vietnam.

MacMillan, D.C. \& Han, J.H. (2011) Cetacean by-catch in the Korean Peninsula-by chance or by design? Human Ecology, $39,757-768$.

Macmillan, D.C., Hanley, N. \& DaW, M. (2004) Costs and benefits of wild goose conservation in Scotland. Biological Conservation, $119,475-485$.

MacMillan, D.C. \& Leader-Williams, N. (2008) When successful conservation breeds conflict: an economic perspective on wild goose management. Bird Conservation International, 18, S200-S210.

MacMillan, D.C. \& Phillip, S. (2010) The role of economic incentives in resolving conservation conflicts: the case of wild deer management and habitat conservation. Human Ecology, $38,485-494$.

Messmer, T.A., George, S.M. \& Cornicelli, L. (1997) Legal considerations regarding lethal and non-lethal approaches to managing urban deer. Wildlife Society Bulletin, 1997, 424-429.

Newing, H., Eagle, C.M., Puri, R.K. \& Watson, C.W. (2011) Conducting Research in Conservation: A Social Science Perspective. Routledge, Abingdon, UK

Newton, P., Nguyen, V.T., Roberton, S. \& Bell, D. (2008) Pangolins in peril: using local hunter's knowledge to conserve elusive species in Vietnam. Endangered Species Research, $6,41-53$.

NGuyen, M.H., Dung, V.V., NGuyen, V.S., Hoang, V.T., Nguyen, H.D, Pham, N.T. et al. (2007) Report on the Review of Vietnam's Wildlife Trade Policy. CRES/FPD/UNEP/CITES/IUED, Hanoi, Vietnam.
Nguyen, Q.T. (2011) An Analysis of the Pilot Project in Lam Dong Province Forest Conservation Project. Occasional Paper No. 5. Institute for Global Environmental Strategies, Kamiyamaguchi, Japan.

Pratt, D.G., MacMillan, D.C. \& Gordon, I.J. (2004) Local community attitudes to wildlife utilisation in the changing economic and social context of Mongolia. Biodiversity and Conservation, 13, 591-613.

Roberton, S.I. (2007) The Status and Conservation of Small Carnivores in Vietnam. PhD thesis. University of East Anglia, Norwich, UK.

Solomon, J., Jacobson, S.K., Wald, K.D. \& Gavin, M. (2007) Estimating illegal resource use at a Ugandan park with the randomised response technique. Human Dimensions of Wildlife, 12, 75-88.

St John, F.A.V., Edwards-Jones, G., Gibbons, J.M. \& Jones, J.P.G. (2010) Testing novel methods for assessing rule breaking in conservation. Biological Conservation, 143, 1025-1030.

Timmins, R.J., Duckworth, J.W. \& Long, B. (2008a) Muntiacus truongsonensis. In IUCN Red List of Threatened Species v. 2010.4. http://www.iucnredlist.org [accessed 17 March 2011].

Timmins, R.J., Duckworth, J.W. \& Long, B. (2008b) Muntiacus vuquangensis. In IUCN Red List of Threatened Species v. 2010.4. http://www.iucnredlist.org [accessed 17 March 2011].

Timmins, R.J., Robichaud, W.G., Long, B., Hedges, S., Steinmetz, R., Abramov, A. et al. (2008c) Pseudoryx nghetinhensis. In IUCN Red List of Threatened Species v. 2010.4. http://www.iucnredlist.org [accessed 17 March 2011].

World Bank (2005) Vietnam Environment Monitor. Http://www. worldbank.org/WBSITE/EXTERNAL/COUNTRIES/ EASTASIAPACIFICEXT/EXTEAPREGTOPENVIRONMENT/o, contentMDK:20739718 pagePK:34004173 piPK:34003707 theSite PK:502886,00.html [accessed 10 January 2011].

\section{Biographical sketches}

Douglas MacMILLAN is interested in the economics of biodiversity conservation, especially the role of financial and other incentives in promoting conservation among local communities. QUOC ANH NGUYEN is now working for WWF-Vietnam on a variety of community-conservation initiatives. 